\title{
PENGARUH DANA PIHAK KETIGA DAN PEMBIAYAAN TERHADAP PROFITABILITAS BANK UMUM SYARIAH DI INDONESIA PERIODE 2014-2018
}

\author{
Tisa Arifi Putriani, Alimatul Farida \\ Universitas Yudharta Pasuruan \\ tisaarifiputriani@gmail.com,farida@yudharta.ac.id
}

\begin{abstract}
Islamic banks are Islamic financial institutions whose main activities are collecting funds from the public or so-called third party funds and channeling them back to the public in the form of financing based on sharia principles with a certain margin so that Islamic banks can obtain profits or profits. The greater the third party funds raised and financing that is distributed, the greater the profit to be obtained. The purpose of this study is to determine whether third party funds and financing have a significant effect on the profitability of Islamic Commercial Banks in Indonesia for the 2014-2018 period. This type of research is a quantitative study using secondary data in the form of financial statements of several Sharia Commercial Banks in Indonesia and data analysis using multiple linear regression analysis methods.

The results of this study indicate that partially Third Party Funds have no significant effect on the profitability of Sharia Commercial Banks in Indonesia with evidence of the results (t test) it is known that a significant value $>0.05$ is equal to 0.411 and $t$ count value $<t$ table that is equal to $0.837<2.069$. Financing also has no significant effect on the profitability of Sharia Commercial Banks in Indonesia with evidence of the results $(\mathrm{t}$ test) it is known that a significant value $>0.05$ is equal to 0.274 and the calculated $t$ value $<\mathrm{t}$ table is equal to $-1,123<2,069$. While simultaneously Third Party Funds and Financing have a significant effect on the profitability of Sharia Commercial Banks in Indonesia with evidence of the results (F test) it is known that a significant value $<0.05$ is equal to 0.047 and a calculated $F$ value $>$ $\mathrm{F}$ table that is equal to $3.516>3.44$.
\end{abstract}

Keywords: Third Party Funds, Financing, and Profitability. 


\section{PENDAHULUAN}

Bank secara sederhana dapat diartikan sebagai lembaga keuangan yang kegiatan utamanya adalah menghimpun dana dari masyarakat dan menyalurkannya kembali dana tersebut ke masyarakat serta memberikan jasa bank lainnya. Menurut Undang-Undang RI Nomor 10 Tahun 1998 tentang Perbankan adalah badan usaha yang menghimpun dana dari masyarakat dalam bentuk simpanan dan menyalurkannya kepada msayarakat dalam bentuk kredit dan/ bentuk-bentuk lainnya dalam rangka meningkatkan taraf hidup rakyat banyak. ${ }^{1}$

Bank Islam atau selanjutnya disebut dengan Bank Syariah adalah bank yang beroperasi dengan tidak mengandalkan pada bunga. Bank Islam atau biasa disebut dengan Bank Tanpa Bunga adalah lebaga keuangan / perbankan yang operasional dan produknya dikembangkan berlandaskan pada Al-Qur'an dan Hadist Nabi SAW. Atau dengan kata lain Bank Islam adalah lembaga keuangan yang usaha pokoknya memberikan pembiayaan dan jasa-jasa lainnya dalam lalu lintas pembayaran serta peredaran uang yang pengoperasiannya disesuaikan dengan prinsip-prinsip syariah Islam. ${ }^{2}$

Perkembangan perusahaan dapat ditinjau oleh manajemen melalui penilaian atas kinerja keuangan dengan menggunakan analisis rasio. Analisis rasio tersebut dapat digunakan oleh manajer keuangan maupun pihak yang memiliki kepentingan untuk memberikan penilaian atas kondisi kesehatan suatu perusahaan. Pada dunia perbankan syariah salah satu rasio yang digunakan oleh perusahaan dalam melakukan penilaian atas kinerja keuangan perusahaan adalah rasio profitabilitas. Profitabilitas merupakan indikator yang paling tepat untuk mengukur kinerja suatu bank. Salah saru rasio yang digunakan untuk mengukur keuntungan adalah rasio Return On Asset (ROA).

Return On Assets (ROA) digunakan untuk mengukur profitabilitas bank karena Bank Indonesia sebagai pembina dan pengawas perbankan lebih mengutamakan nilai profitabilitas suatu bank yang diukur dengan aset yang dananya sebagian besar dari dana simpanan masyarakat. Semakin besar ROA suatu bank, semakin besar pula tingkat keuntungan yang dicapai bank, dan semakin baik posisi bank tersebut dari segi penggunaan aset. ${ }^{3}$

Dalam upaya memperoleh keuntungan yang maksimal, bank syariah memegang prinsip-prinsip syariat dalam mengelola aset dan memegang

\footnotetext{
${ }^{1}$ Kasmir, Manajemen Perbankan Edisi Revisi, (Jakarta: Rajawali Pers, 2015), 12-13.

2 Ibid, 2

${ }^{3}$ Dendawijaya, Manajemen Perbankan, (Jakarta: Ghalia Indonesia, 2009), 118.
} 
kepercayaan nasabah berupa tanggung jawab pemenuhan kewajibannya sebagai lembaga yang sangat bergantung dari asas kepercayaan. Diantara beberapa faktor yang mempengaruhi jumlah keuntungan yang diterima Bank Syariah adalah jumlah dana pihak ketiga yang mampu dihimpun bank, dimana semakin besar dana nasabah yang dihimpun produk bank syariah maka aset yang dimiliki pun akan semakin besar yang dapat digunakan untuk menyalurkan pembiayaan dan salah satu tolak ukur kesehatan bank. Faktor lainnya adalah pembiayaan yang disalurkan bank, dimana semakin besar pembiayaan yang disalurkan bank syariah maka margin bagi hasil yang diterima pihak bank juga semakin besar, hal ini merupakan motivasi untuk bank syariah agar mampu menjalankan pembiayaan yang lancar dan terpercaya. ${ }^{4}$

Menurut statistik perbankan syariah yang diterbitkan oleh Otoritas Jasa Keuangan menyatakan secara nasional volume usaha perbankan syariah yang terdiri atas total aset, total dana pihak ketiga dan total pembiayaan yang disalurkan perbankan syariah mengalami peningkatan. Total aset pada tahun 2017 yang hanya sebesar Rp. 267,570 Miliar meningkat menjadi Rp. 298.044 Miliar, total dana pihak ketiga pada tahun 2017 sebesar Rp. 283,393 Miliar menurun menjadi Rp. 257,606, sedangkan total pembiayaan pada tahun 2017 sebesar Rp. 190,354 Miliar juga meningkat menjadi Rp. 202,766 Miliar. ${ }^{5}$

Adapun data mengenai dinamika rasio-rasio keuangan perbankan syariah pada tahun 2014-2018 disajikan dalam tabel berikut :

\section{Laporan Rasio Keuangan Perbankan Syariah Periode 2014-2018}

\begin{tabular}{|l|c|c|c|c|c|}
\hline \multirow{2}{*}{ Rasio Keuangan } & \multicolumn{5}{|c|}{ Tahun } \\
\cline { 2 - 6 } & 2014 & 2015 & 2016 & 2017 & 2018 \\
\hline DPK & 170.723 & 174.895 & 206.407 & 283.393 & 257.606 \\
\hline Pembiayaan & 148.425 & 154.527 & 178.043 & 190.354 & 202.766 \\
\hline $\begin{array}{l}\text { Profitabilitas } \\
\text { (ROA)\% }\end{array}$ & $0,41 \%$ & $0,49 \%$ & $0,63 \%$ & $0,63 \%$ & $1,28 \%$ \\
\hline
\end{tabular}

Sumber : Laporan Rasio Keuangan Tahunan yang diolah 2019

\footnotetext{
4 Annisa Khairani Lubis, Pengaruh Dana Pihak Ketiga, Pembiayaan, dan Modal Terhadap Laba Pada PT. Bank Syariah Mandiri, (Skripsi Tidak Diterbitkan, Medan: UIN Sumatera, 2017).

${ }^{5}$ www.ojk.go.id diakses pada tanggal 11 Mei 2019 pukul 22.06.
} 
Pada diatas menunjukkan bahwa jumlah DPK mengalami kenaikan pada tahun 2014 sampai 2017, namun pada tahun 2018 mengalami penurunan. Sedangkan pembiayaan dan ROA mengalami kenaikan pada tahun 2014 sampai 2018, namun pada tahun 2017 rasio ROA tidak mengalami perubahan atau sama dengan 2016.

\section{KAJIAN TEORI}

\section{Profitabilitas}

\section{a. Pengertian Profitabilitas}

Profitabilitas sebagai salah satu acuan dalam mengukur besarnya laba menjadi begitu penting untuk mengetahui bahwa perusahaan telah menjalankan usahanya secara efisien. Profitabilitas merupakan suatu kemampuan bank dalam menghasilkan laba selama periode tertentu yang dinyatakan dalam prosentase. ${ }^{6}$ Bank yang sehat adalah bank yang dilihat dari profitabilitas atau rentabilitas yang terus meningkat di atas standar yang ditetapkan. Profitabilitas merupakan kemampuan bank dalam menghasilkan laba secara efektif dan efisien. ${ }^{7}$ Profitabilitas adalah kemampuan bank dalam memperoleh laba ditunjukkan keuntungan yang dihasilkan. ${ }^{8}$

Rasio profitabilitas digolongkan menjadi dua, yaitu Return On Equity (ROE) dan Return On Assets (ROA). Return On Equity (ROE) merupakan rasio profitabilitas yang menunjukkan perbandingan antara laba (setelah pajak) dengan modal (modal inti) bank, rasio ini menunjukkan tingkat persentase yang dapat dihasilkan dalam mengelola modal yang tersedia untuk mendapat net income. Kedua adalah Return On Assets (ROA) merupakan rasio profitabilitas yang menunjukkan perbandingan laba (sebelum pajak) dengan total assets bank. $^{9}$

\footnotetext{
${ }^{6}$ Riyanto, Dasar-Dasar Pembelanjaan Perusahaan, (Yogyakarta: BPFE, 2008), 35.

${ }^{7}$ Dendawijaya, Manajemen Perbankan, (Jakrta: Ghalia Indonesia, 2009), 118.

8 Simorangkir, Lembaga Keuangan Bank Dan Non Bank, (Jakarta: Fakultas Ekonomi Universitas Indonesia, 2004), 156.

${ }_{9}^{9}$ Giofani Nursucia, Pengaruh Capital Adequacy Ratio (CAR), Non Performing Financing (NPF), Operational Efficiency Ratio (OER), Penyisihan Penghaspusan Aktiva Produktif (PPAP), Dan Net Operating Margin (NOM) Terhadap Profitabilitas Pada Bank Umum Syariah Periode 2010-2015, (Skripsi Tidak Diterbitkan, Yogyakarta: Universitas Negeri Yogyakarta, 2017), 11.
} 


\section{b. Cara Mengukur Profitabilitas}

Profitabilitas merupakan indikator yang paling tepat untuk mengukur kinerja suatu bank. Menurut Karya dan Rakhman, tingkat profitabilitas bank syariah di Indonesia merupakan yang terletak di dunia dari rasio laba terhadap asset (ROA), baik untuk kategori bank yang full fletge maupun untuk kategori unit usaha syariah. ${ }^{10}$

Return On Assets (ROA) digunakan untuk mengukur profitabilitas bank karena Bank Indonesia sebagai pembina dan pengawas perbankan lebih mengutamakan nilai profitabilitas suatu bank yang diukur dengan aset yang dananya sebagian besar dari dana simpanan masyarakat. Semakin besar ROA suatu bank, semakin besar pula tingkat keuntungan yang dicapai bank, dan semakin baik posisi bank tersebut dari segi penggunaan aset. ${ }^{11}$ Teknik untuk menghitung Return On Assets (ROA) sebagai berikut:

Return On Equity (ROE) juga merupakan salah satu rasio yang digunakan untuk mengukur profitabilitas. ROE adalah perbandingan antara laba bersih setelah pajak dengan modal sendiri (equity) merupakan indokator yang amat penting bagi para pemegang saham dan calon investor untuk mengukur kemampuan bank dalam memperoleh laba bersih yang dikaitkan dengan pembayaran deviden. Teknik untuk menghitung Return On Equity (ROE) sebagai berikut:

\section{Dana Pihak Ketiga}

\section{a. Pengertian Dana Pihak Ketiga}

Menurut Kasmir, dana pihak ketiga adalah dana yang dihimpun oleh bank yang berasal dari masyarakat, yang terdiri dari simpanan giro, simpanan tabungan dan simpanan deposito. Dana pihak ketiga yang dihimpun dari masyarakat luas merupakan sumber dana terpenting bagi operasional bank dan merupakan ukuran keberhasilan bank jika mampu membiayai operasinya dari sumber dana ini. Pencarian dana ini relatif paling mudah jika dibandingkan dengan sumber lainnya. ${ }^{12}$ Peningkatan dana pihak ketiga perbankan syariah disebabkan karena kepercayaan masyarakat terhadap

\footnotetext{
${ }^{10} \mathrm{Ibid}, 14$.

${ }^{11}$ Dendawijaya, Manajemen Perbankan, (Jakarta: Ghalia Indonesia, 2009), 118.

${ }^{12}$ Kasmir, Manajemen Perbankan Edisi Revisi (Jakarta: PT. Raja Grrafindo Persada, 2014), 53.
} 
perbankan syariah semakin baik dari tahun ke tahun. Ini merupakan indikasi yang cukup baik bagi perbankan syariah untuk terus melakukan sosialisasi dan pendekatan kepada masyarakat akan manfaat yang diperoleh dari jasa perbankan syariah dibandingkan perbankan umum.

\section{b. Jenis-Jenis Produk Dana Pihak Ketiga}

1) Simpanan Giro

Pengertian giro menurut Undang-Undang Perbankan Nomor 10 Tahun 1998 tanggal 10 November 1998 adalah simpanan yang penarikannya dapat dilakukan setiap saat dengan menggunakan cek, bilyet giro, sarana perintah pembayaran lainnya atau dengan cara pemindahan bukuan. Dapat ditarik setiap saat, maksudnya bahwa uang yang disimpan di rekening giro tersebut dapat ditarik berkali-kali dalam sehari, dengan catatan dana yang tersedia masih mencukupi. Kemudian juga harus memenuhi persyartan yang lain yang ditetapkan oleh bank yang bersangkutan seperti keabsahan alat penarikannya. ${ }^{13}$

Simpanan giro dalam prinsip perbankan syariah dibedaka menjadi dua, diantaranya sebagai berikut:

a) Giro wadiah

Giro wadiah adalah giro yang dijalankan berdasarkan akad wadiah, yakni titipan murni yang setiap saat dapat diambil jika pemiliknya menghendaki. Dalam konsep wadiah yad al-dhamanah, pihak yang menerima titipan boleh menggunakan atau memanfaatkan uang atau barang yang dititipkan. Hal ini berarti bahwa wadiah yad dhamanah mempunyai implikasi hukum yang sama dengan qard, yakni nasabah bertindak sebagai pihak yang meminjamkan uang dan bank bertindak sebagai pihal yang dipinjami. Dengan demikian, pemilik dana dan bank tidak boleh saling menjanjikan untuk memberikan imbalan atas penggunaan atau pemanfaatan dana atau barang titipam tersebut. ${ }^{14}$

13 Idib., 55-56.

14 Adimarwan A. Karim, Bank Islam: Analisis Fiqih dan Keuangan, (Jakarta: PT. RajaGrafindo Persada, 2014), 351-352. 


\section{b) Giro Mudharabah}

Giro Mudharabah adalah giro yang dijalankan berdasarkan akad Mudharabah. Mudharabah mempunyai dua bentuk, yakni Mudharabah mutlaqah dan Mudharabah muqayyadah, yang perbedaan utama diantara keduanya terletak pada ada atau tidaknya persyaratan yang diberikan pemilik dana kepada bank dalam mengelola hartanya, baik dari sisi tempat, waktu, maupun objek investasinya. ${ }^{15}$

\section{2) Simpanan Tabungan}

Jenis simpanan yang dilakukan oleh pihak ketiga yang penarikannya dilakukan menurut syarat tertentu sesuai perjanjian antara bank dan pihak nasabah. Menurut pasal 1 nomor 21 Undang-undang No. 21 Tahun 2008, Tabungan adalah simpanan berdasarkan akad wadiah/investasi dana berdasarkan akad Mudharabah/akad lain yang tidak bertentangan dengan prinsip syariah yang penarikannya hanya dapat dilakukan menurut syarat dan ketentuan tertentu yang disepakati, tetapi tidak dapat ditarik dengan cek, bilyet giro, dan/atau alat lainnya yang dipersamakan dengan itu. ${ }^{16}$

Simpanan tabungan dalam prinsip perbankan syariah dibedaka menjadi dua, diantaranya sebagai berikut:

a) Tabungan $\mathrm{Wad}$ 'ah

Tabungan wadiah adalah tabungan yang dijalankan berdasarkan akad wadiah, yakni titipan murni yang harus dijaga dan dikembalikan setiap saat sesuai dengan kehendak pemiliknya. Berkaitan dengan tabungan produk tabungan wadiah, bank syariah menggunakan akad wadiah yad dhamanah. Dalam hal ini, nasabah bertindak sebagai penitip yang memberikan hak kepada Bank Syariah untuk menggunakan atau memanfaatkan uang atau barang titipannya, sedangkan Bank Syariah bertindak sebagai pihak yang dititipi dana atau barang tersebut. Sebagai konsekuensinya bank bertanggung jawab terhadap keutuhan harta titipan tersebut serta mengembalikannya kapan saja pemiliknya menghendaki.

15 Ibid, 354-356.

${ }^{16}$ Kasmir, Manajemen Perbankan Edisi Revisi, (Jakarta: PT. RajaGrafindo Persada, 2014), 63-64. 
Disisi lain, bank juga berhak sepenuhnya atas keuntungan dari hasil penggunaan atau pemanfaatan dana atau barang tersebut. $^{17}$

b) Tabungan Mudharabah

Tabungan Mudharabah adalah tabungan yang dijalankan berdasarkan akad Mudharabah. Mudharabah mempunyai dua bentuk, yakni Mudharabah mutlaqah dan Mudharabah muqayyadah, yang perbedaan utama di antara keduanya terletak pada ada atau tidaknya persyaratan yang diberikan pemilik dana kepada bank dalam mengelola hartanya. ${ }^{18}$

Dalam hal ini, bank bertindak sebagai mudharib (pengelola dan), sedangkan nasabah bertindak sebagai shahibul mal (pemilik dana). Bank syariah dalam kapasitasnya sebagai mudharib, mempunyai kuasa untuk melakukan berbagai macam usaha yang bertentangan dengan prinsip syariah serta mengembangkannya, termasuk melakukan akad Mudharabah dengan pihak lain. Namun, disisi lain, bank syariah juga memiliki sifat sebagai seorang wali amanah (trustee), yang berarti bank harus berhati-hati atau bijaksana serta beriktikad baik dan bertanggung jawab atas segala sesuatu yang timbul akibat kesalahan atau kelalaiannya.

3) Simpanan Deposito

Menurut Undang-Undang Nomor 10 tahun 1998, deposito adalah simpanan yang penarikannya hanya dapat dilakukan pada waktu tertentu berdasarkan perjanjian nasabah penyimpan dengan bank yang bersangkutan. Adapun yang dimakasud deposito syariah adalah deposito yang dijalankan berdasarkan prinsip syariah. Dalam hai ini, Dewan Syariah Nasional MUI telah mengeluarkan fatwa yang menyatakan bahwa deposito yang dibenarkan adalah deposito yang berdasarkan prinsip Mudharabah. ${ }^{19}$ Deposito Mudharabah terbagi menjadi 2 jenis yaitu sebagai berikut:

17 Adimarwan A. Karim, Bank Islam: Analisis Fiqih dan Keuangan, (Jakarta: PT. RajaGrafindo Persada, 2014), 357-358.

18 Ibid., 359-361.

19 Ibid., 363-364. 
a) Deposito Mudharabah Muthlaqoh

Pemilik dana tidak memberikan batasan atau persyaratan tertentu kepada Bank Syariah dalam mengelola investasinya, baik yang berkaitan dengan tempat, cara maupun objek investasinya. Dengan kata lain, bank syariah mempunyai hak dan kebebasan sepenuhnya dalam menginvestasikan dana ini ke berbagai sektor bisnis yang diperkirakan akan memperoleh keuntungan.

b) Deposito Mudharabah Muqayyadah

Berbeda halnya dengan deposito Mudharabah Muthlaqoh, dalam deposito Mudharabah Muqayyadah, pemilik dana memberikan batasan atau persyaratan tertentu kepada Bank Syariah dalam mengelola investasinya baik yang berkaitan dengan tempat, cara, maupun objek investasinya. Dengan kata lain, Bank Syariah tidak mempunyai hak dan kebebasan sepenuhnya dalam menginvestasikan dana ini ke berbagai sektor bisnis yang diperkirakan akan memperoleh keuntungan. $^{20}$

\section{Pembiayaan}

\section{a. Pengertian Pembiayaan}

Menurut UU No. 10 Tahun 1998 pasal 1 No. 12 Pembiayaan adalah penyediaan uang berdasarkan kesepakatan antara bank dengan nasabah untuk mengembalikan uang tersebut setelah jangka waktu tertentu dengan imbalan. ${ }^{21}$ Menurut M. Syafi'i Antonio, Pembiayaan adalah pemberian fasilitas penyediaan dana untuk memenuhi kebutuhan pihak-pihak yang defisit unit. ${ }^{22}$

\section{b. Fungsi Pembiayaan}

Secara terperinci pembiayaan memiliki fungsi antara lain: ${ }^{23}$

1) Pembiayaan dapat menimbulkan arus tukar menukar barang dan jasa.

Ibid., 367.

${ }^{21}$ Kasmir, Manajemen Perbankan Edisi Revisi, (Jakarta: PT. Raja Grafindo Persada, 2014), 81.

${ }^{22}$ Muhammad Syafi “i Antonio, Bank Syariah dari Teori ke Praktik, (Jakarta: Gema Insani, 2011), 160 . 
2) Pembiayaan merupakan alat yang dipakai untuk memanfaatkan idle fund. Maksudnya disini, bank dapat mempertemukan pihak yang kelebihan dana dengan pihak yang memerlukan dana.

3) Pembiayaan dapat meningkatkan manfaat ekonomi yang ada.

\section{c. Tujuan Pembiayaan}

Adapun tujuan utama pemberian suatu pembiayaan adalah sebagai berikut: ${ }^{23}$

1) Mencari keuntungan dari pembiayaan yang telah disalurkan tersebut.

2) Membantu usaha nasabah yang memerlukan dana.

3) Membantu pemerintah yang mana semakin banyak pembiayaan yang disalurkan oleh pihak perbankan, maka akan semakin baik.

\section{d. Prinsip-Prinsip Syariah dalam Pembiayaan}

1) Prinsip Jual Beli $\left(B a{ }^{\prime} i\right)$

a) Pembiayaan Murabahah

Murabahah adalah akad jual beli antara bank selaku penyedia barang, dan nasabah yang memesan untuk membeli barang dagang, bank memperoleh keuntungan yang disepakati bersama. Berdasarkan akad jual beli dimaksud, bank membeli barang yang dipesan dan menjualnya kepada nasabah harga jual bank adalah harga beli dan supplier ditambah keuntungan yang disepakati. Oleh karena itu, nasabah mengetahui besarnya keuntungan yang diambil bank. Cara pembayaran dan jangka waktunya disepakati bersama, dengan cara angsuran. $^{24}$

b) Pembiayaan Salam

Secara etimologi, salam artinya salaf (pendahuluan). Secara terminologi muamalah salam adalah penjualan barang yang disebutkan sifat-sifatnya sebagai persyaratan jual beli dan barang tersebut masih dalam tanggungan penjual. Syaratsyarat tersebut diantaranya adalah mendahulukan pembayaran pada waktu akad. Salam adalah akad jual beli atas suatu

23 Ismail, Perbankan Syariah, (Jakarta: Kencana, 2011), 108-109.

${ }^{24}$ Herry Sutanto dan Khaerul Umam, Manajemen Pemasaran Bank Syariah, (Bandung: Pustaka Setia, 2013), 181. 
barang dengan jenis dan dalam jumlah tertentu yang penyerahannya dilakukan beberapa waktu kemudian, sedangkan pembayaran segera (di muka).

Salam paralel merupakan dua transaksi salam yang dilakukan secara simultan dan melibatkan tiga pihak yang berkepentingan salah satu di antaranya bertindak sebagai pembeli dan sekaligus penjual. Yang dimaksud penjual adalah membeli suatu barang dari pihak kedua dan menjualnya kembali kepada pihak ketiga. ${ }^{25}$

c) Pembiayaan Istishna'

Istishna adalah akad jual beli barang berdasarkan pesanan antara nasabah sebagai pemesan dan bank dengan kriteria tertentu, seperti jenis, tipe, kualitas, dan jumlahnya. Bank akan memberikan barang pesanan nasabah tersebut kepada pemasok dengan kriteria yang sesuai. Harga, cara pembayaran, dan jangka waktu penyerahan barang pesanan tersebut disepakati bersama. Apabila pesanan mengizinkan untuk meminta pihak ketiga (sub-pemasok) pembuat barang pesanan tersebut, transaksi ini disebut Istishna paralel. ${ }^{26}$

2) Prinsip Bagi Hasil

a) Pembiayaan Mudharabah

Menurut Undang-Undang No. 21 Tahun 2008 tentang Perbankan Syariah, mudaharabah yaitu akad kerjasama suatu usaha antara pihak pertama (malik, shahibul mall, atau bank syariah) yang menyediakan seluruh modal dan pihak kedua (,amil, mudharib, atau nasabah) yang bertindak selaku pengelola dana dengan membagi keuntungan usaha sesuai dengan kesepakatan yang dituangkan dalam akad, sedangkan kerugian ditanggung sepenuhnya oleh bank syariah kecuali jika pihak kedua melakukan kesalahan yang disengaja, lalai, atau menyalahi perjanjian. ${ }^{27}$

${ }^{25}$ Veithzal Rivai dan Andria Pratama Veithzal, Islamic Financial Management, (Jakarta: Gaya Media Pratama, 2007), 173.

26 Ibid., 195.

27 Mardani, Hukum Bisnis Islam, (Jakarta: Kencana, 2014), 138. 
b) Pembiayaan Musyarakah

Menurut Undang-Undang No.21 Tahun 2008 tentang Perbankan Syariah, Musyarakah yaitu akad kerja sama di antara dua pihak atau lebih untuk suatu usaha tertentu yang masing-masing pihak memberikan porsi dana dengan ketentuan bahwa keuntungan akan dibagi sesuai dengan kesepakatan, sedangkan kerugian ditanggung sesuai porsi dana masing-masing. ${ }^{28}$

3) Prinsip Sewa

a) Pembiayaan dengan prinsip sewa (Ijarah)

Transaksi Ijarah dilandasi oleh adanya perpindahan manfaat (hak guna), bukan perpindahan kepemilikan (hak milik). Jadi pada dasarnya prinsip Ijarah sama saja dengan prinsip jual beli, tapi perbedaannya terletak pada objek transaksinya. Bila pada jual beli objek transaksinya barang, pada Ijarah objek transaksinya adalah barang maupun jasa.

b) Pembiayaan dengan prinsip Ijarah Mumtahia Bit Tamlik (IMBT)

Ijarah Mumtahia Bit Tamlik (IMBT) merupakan rangkaian dua buah akad, yakni akad al Ba'i dan akad Ijarah Muntahia Bittamlik (IMBT). Al Ba'i merupakan akad jual beli, sedangkan IMBT merupakan kombinasi antara sewa menyewa (Ijarah) dan jual beli atau hibah di akhir masa sewa. Pada alBa'i wal Ijarah Muntahia Bittamlik (IMBT) dengan sumber pembiayaan, pembayaran oleh nasabah dilakukan secara bulanan. Hal ini disebabkan karena pihak bank harus mempunyai cash in setiap bulan untuk memberikan bagi hasil kepada para nasabah yang dilakukan secara bulanan juga.

4) Prinsip Kebajikan

a) Qardh dan Qardhul Hasan

Secara etimologi, qardh berarti potongan, sedangkan secara terminologi berarti pemberian harta kepada orang lain yang dapat diminta kembali dengan jumlah yang sama atau dengan kata lain meminjamkan tanpa mengharapkan imbalan

\footnotetext{
${ }^{28}$ Mardani, Hukum Bisnis Islam, (Jakarta: Kencana, 2014), 142.
} 
atau tambahan. ${ }^{29}$ Sedangkan qardhul hasan yaitu jenis pinjaman yang diberikan kepada pihak yang sangat memerlukan untuk jangka waktu tertentu tanpa harus membayar bunga atau keuntungan. Penerima qardhul hasan hanya berkewajiban melunasi jumlah pinjaman pokok tanpa diharuskan memberikan tambahan apapun. Namun penerima pinjaman boleh saja atas kebajikannya sendiri membayar lebih dari uang yang dipinjamnya sebagai tanda terima kasih kepada pemberi pinjaman. Tetapi hal tersebut tidak boleh diperjanjikan sebelumnya di muka. ${ }^{30}$

\section{METODE}

\section{Rancangan Penelitian}

Penelitian ini merupakan jenis penelitian kuantitatif dengan menggunakan pendekatan asosiatif. Menurut Creswell bahwa penelitian kuantitatif yakni penyelidikan tentang masalah kemasyarakatan atau kemanusiaan yang didasarkan pada pengujian suatu teori yang tersusun atas variabel-variabel, diukur dengan bilangan-bilangan, dan dianalisis dengan prosedur-prosedur statistik. Tujuannya adalah menentukan apakah generalisasi-generalisasi prediktif dari teoti tertantu yang diselidiki terbukti kebenarannya. ${ }^{31}$ Sedangkan pendekatan asosiatif merupakan bentuk analisis data penelitian untuk menguji ada tidaknya hubungan keberadaan variabel dari dua kelompok data atau lebih. ${ }^{32}$

\section{Populasi dan Sampel Penelitian}

Populasi dalam penelitian ini adalah laporan keuangan Annual Report setiap Bank Umum Syariah Di Indonesia yang dipublikasikan pada periode 2014-2018. Teknik pemilihan sampel yang digunakan adalah probability sampling yaitu teknik pengambilan sampel yang memberikan peluang yang sama bagi setiap unsur (anggota) populasi

\footnotetext{
${ }^{29}$ Muhammad Syafi"i Antonio, Bank Syariah dari Teori ke Praktik, (Jakarta: Gema Insani, 2011), 131.

${ }^{30}$ Sultan Remy Sjahdeini, Perbankan Syariah Produk-Produk dan Aspek-Aspek Hukumnya, (Jakarta: Kencana, 2014), 342-343.

${ }^{31}$ Rahmat Trijono, Metode Penelitian Kuantitatif, (Jakarta: Penerbit Papas Sinar Sinanti, tahun 2015). 17.

${ }^{32}$ Syofian Siregar, Metode Penelitian Kuantitatif, (Jakarta: Prenada Media Group, 2013), 101.
} 
untuk dipilih menjadi anggota sampel. ${ }^{33}$ Sampel dalam penelitian ini adalah laporan keuangan Annual Report 5 Bank Umum Syariah yang dipublikasikan pada periode 2014-2018 yakni Bank Syariah Mandiri, Bank BNI Syariah, Bank BRI Syariah, Bank Muamalat dan BCA Syariah.

\section{Instrumen Penelitian}

Instrumen penelitian yang digunakan untuk memperoleh data dalam penelitian ini adalah studi dokumentasi melalui website resmi atau arsip-arsip data sekunder. Website resmi yang digunakan untuk memperoleh data dalam penelitian ini adalah website resmi dari setiap perbankan syariah yang menjadi sampel dalam penelitian ini diantaranya dari Bank Muamalat Indonesia, Bank BCA Syariah, Bank BNI Syariah, Bank BRI Syariah, dan Bank Syariah Mandiri.

\section{Analisis Data}

Analisis data yang digunakan dalam penelitian ini adalah analisi regresi linier berganda. Analisi liniear berganda bertujuan untuk melihat pengaruh antara variabel independen dan variabel dependen dengan skala pengukuran atau rasio dalam suatu persamaan linier. ${ }^{34}$ Pada penelitian ini digunakan untuk menganalisi data dua variabel independen yaitu dana pihak ketiga $\left(\mathrm{X}_{1}\right)$ dan pembiayaan $\left(\mathrm{X}_{2}\right)$, serta sebuah variabel dependen yaitu profitabilitas $(\mathrm{Y})$ yang diolah dengan perangkat lunak SPSS.

\section{PEMBAHASAN}

\section{Pengaruh Dana Pihak Ketiga Terhadap Profitabilitas}

Menurut Kasmir, dana pihak ketiga adalah dana yang dihimpun oleh bank yang berasal masyarakat, yang terdiri dari simpanan gito, simpanan tabungan, dan simpanan deposito. Dana pihak ketiga yang dihimpun dari masyarakat luas merupakan sumber dana terpenting bagi operasional bank dan merupakan ukuran keberhasilan bank jika mampu membiayai operasinya dari sumber dana ini. Dana pihak ketiga yang telah dihimpun oleh bank syariah kemudian akan disalurkan kembali kepada masyarakat melalui pembiayaan agar bank syariah dapat menghasilkan profit. Profitabilitas merupakan suatu kemampuan bank dalam menghasilkan laba/profit selama periode tertentu yang dnyatakan dalam prosentase.

\footnotetext{
${ }^{33}$ V. Wiratna Sujarweni,Metodologi Penelitian Bisnis dan Ekonomi, (Yogyakarta: Pustaka Baru Press, 2015), 85.

${ }^{34}$ Ibid., 227.
} 
Apabila semakin besar dana pihak ketiga yang dihimpun oleh perbankan syariah maka semakin besar pula pembiayaan yang dapat disalurkan oleh bank syariah yang kemudian akan meningkatkan pula profit yang didapatkan. Sehingga prosentase profitabilitas bank syariah juga akan meningkat dan dapat diartikan bahwa dana pihak ketiga berpengaruh terhadap profitabilitas bank syariah.

Namun pada penelitian ini diperoleh hasil analisis uji secara parsial (uji t) pada tabel berikut:

\section{Hasil Uji Parsial (Uji t)}

Coefficients $^{\text {a }}$

\begin{tabular}{|c|c|c|c|c|c|c|c|}
\hline \multirow[b]{2}{*}{ Model } & \multicolumn{2}{|c|}{$\begin{array}{l}\text { Unstandardized } \\
\text { Coefficients }\end{array}$} & \multirow{2}{*}{$\begin{array}{c}\text { Standardized } \\
\text { Coefficients } \\
\text { Beta }\end{array}$} & \multirow[b]{2}{*}{$\mathrm{t}$} & \multirow[b]{2}{*}{ Sig. } & \multicolumn{2}{|c|}{$\begin{array}{l}\text { Collinearity } \\
\text { Statistics }\end{array}$} \\
\hline & B & Std. Error & & & & Tolerance & VIF \\
\hline 1 (Constant) & 1.080 & .156 & & 6.934 & .000 & & \\
\hline Dana Pihak Ketiga & $2.618 \mathrm{E}-5$ & .000 & 1.342 & .837 & 411 & .013 & 74.547 \\
\hline Pembiayaan & $-4.420 \mathrm{E}-5$ & .000 & -1.800 & -1.123 & .274 & .013 & 74.547 \\
\hline
\end{tabular}

a. Dependent Variable: Profitabilitas (ROA)

Sumber : data diolah pada tahun 2019

Berdasarkan nilai signifikan $>0,05$ yakni sebesar 0,411 dan nilai $t$ hitung $<\mathrm{t}$ tabel yakni sebesar $0,837<2,069$. Angka tersebut menunjukan nilai yang tidak signifikan dan berarti tidak terdapat pengaruh signifikan antara dana pihak ketiga terhadap profitabilitas bank umum syariah periode 2014-2018. Sehingga penyataan $\mathrm{Hp}_{1}$ ditolak. Hasil penelitian ini berbeda dengan hasil penelitian yang dilakukan oleh Annisa Khairani Lubi (2017) yang mana hasil penelitiannya adalah dana pihak ketiga berpengaruh signifikan terhadap profitabilitas.

\section{Pengaruh Pembiayaan Terhadap Profitabilitas}

Menurut Undang-Undang No. 10 Tahun 1998 pasal 1 No. 12 Pembiayaan adalah penyediaan uang yang berdasarkan kesepakatan antara bank dengan pihak lain atau nasabah yang mewajibkan pihak lain atau nasabah untuk mengembalikan uang tersebut setelah jangka waktu tertentu dengan imbalan atau bagi hasil. Imbalan atau bagi hasil yang diterima oleh bank syariah tersebut yang menjadi profit/laba yang 
diperoleh bank syariah atas kegiatan usaha yang dijalankan. Profitabilitas merupakan suatu kemampuan bank dalam menghasilkan laba/profit selama periode tertentu yang dnyatakan dalam prosentase.

Oleh karena itu, apabila pembiayaan yang disalurkan oleh bank syariah meningkat maka akan meningkat pula margin bagi hasil atau profit yang diperoleh bank syariah. Sehingga prosentase profitabilitas bank syariah juga akan meningkat dan dapat diartikan bahwa pembiayaan berpengaruh terhadap profitabilitas bank syariah.

Namun pada penelitian ini, diperoleh hasil analisis uji secara parsial (uji t) pada tabel berikut:

\section{Hasil Uji Parsial (Uji t)}

Coefficients $^{\mathbf{a}}$

\begin{tabular}{|c|c|c|c|c|c|c|c|}
\hline \multirow[b]{2}{*}{ Model } & \multicolumn{2}{|c|}{$\begin{array}{l}\text { Unstandardized } \\
\text { Coefficients }\end{array}$} & \multirow{2}{*}{$\begin{array}{c}\text { Standardized } \\
\text { Coefficients } \\
\text { Beta }\end{array}$} & \multirow[b]{2}{*}{$\mathrm{t}$} & \multirow[b]{2}{*}{ Sig. } & \multicolumn{2}{|c|}{$\begin{array}{l}\text { Collinearity } \\
\text { Statistics }\end{array}$} \\
\hline & B & Std. Error & & & & Tolerance & VIF \\
\hline 1 (Constant) & 1.080 & 156 & & 6.934 & .000 & & \\
\hline Dana Pihak Ketiga & $2.618 \mathrm{E}-5$ & .000 & 1.342 & .837 & 411 & .013 & 74.547 \\
\hline Pembiayaan & $-4.420 \mathrm{E}-5$ & .000 & -1.800 & -1.123 & .274 & .013 & 74.547 \\
\hline
\end{tabular}

a. Dependent Variable: Profitabilitas (ROA)

Sumber : data diolah pada tahun 2019

Berdasarkan nilai signifikan $>0,05$ yakni sebesar 0,274 dan nilai $t$ hitung $t$ tabel yakni sebesar $-1,123<2,069$. Angka tersebut menunjukkan nila yang tidak signifikan dan berarti tidak terdapat pengaruh signifikan antara pembiayaan terhadap profitabilitas bank umum syariah periode 2014-2018. Sehingga pernyataan $\mathrm{Hp}_{2}$ ditolak. Hasil penelitian ini juga berbeda dengan hasil penelitian yang dilakukan oleh Annisa Khairani Lubis (2017) yang mana hasil penelitiannya adalah pembiayaan berperngaruh secara signifikan terhadap profitabilitas.

\section{Pengaruh Dana Pihak Ketiga dan Pembiayaan Secara Simultan Terhadap Profitabilitas}

Menurut Kasmir, dana pihak ketiga adalah dana yang dihimpun oleh bank yang berasal masyarakat, yang terdiri dari simpanan gito, simpanan tabungan, dan simpanan deposito. Dana pihak ketiga yang 
dihimpun dari masyarakat luas merupakan sumber dana terpenting bagi operasional bank. Sedangkan pembiayaan menurut UU No. 10 Tahun 1998 pasal 1 No. 12 adalah penyediaan uang yang berdasarkan kesepakatan antara bank dengan pihak lain atau nasabah yang mewajibkan pihak lain atau nasabah untuk mengembalikan uang tersebut setelah jangka waktu tertentu dengan imbalan atau bagi hasil. Dana pihak ketiga yang telah dihimpun oleh bank syariah dari masyarakat akan disalurkan kembali kepada masyarakat dalam bentuk pembiayaan dan mewajibkan untuk mengembalikan dana tersebut dalam jangka waktu tertentu dengan imbalan / margin / bagi hasil sehingga bank syariah bisa memperoleh profit. Profitabilitas merupakan suatu kemampuan bank dalam menghasilkan laba/profit selama periode tertentu yang dnyatakan dalam prosentase.

Apabila dana pihak ketiga dan pembiayaan meningkat maka profit yang akan dihasilkan juga akan meningkat. Sehingga prosentase profitabilitas bank syariah juga akan meningkat dan dapat diartikan bahwa dana pihka ketiga dan pembiayaan berpengaruh terhadap profitabilitas bank syariah.

Pada hasil penelitian ini diperoleh hasil analisis secara simultan (uji F) pada tabel berikut :

Hasil Uji Simultan (F)

\begin{tabular}{|c|c|c|c|c|c|}
\hline \multicolumn{6}{|c|}{ ANOVA $^{b}$} \\
\hline Model & Sum of Squares & $\mathrm{df}$ & Mean Square & $\mathrm{F}$ & Sig. \\
\hline 1 Regression & 1.315 & 2 & .657 & 3.516 & $.047^{\mathrm{a}}$ \\
\hline Residual & 4.114 & 22 & 187 & & \\
\hline Total & 5.429 & 24 & & & \\
\hline
\end{tabular}

a. Predictors: (Constant), Pembiayaan, Dana Pihak Ketiga

b. Dependent Variable: Profitabilitas (ROA)

Sumber : data diolah pada tahun 2019

Berdasarkan nilai signifikan $<0,05$ yakni sebesar 0,047 dan nilai F hitung > F tabel yakni sebesar 3,516> 3,44 yang berarti terdapat perngaruh signifikan secara simultan antara dana pihak ketiga dan pembiayaan terhadap profitabilitas. Sehingga pernyataan $\mathrm{Hp}_{3}$ diterima. 
Hasil penelitian ini juga sesuai dengan hasil penelitian yang dilakukan oleh Seli Giantini (2015) bahwa dana pihak ketiga dan pembiayaan secara simultan berpengaruh signifikan terhadap profitabilitas.

\section{KESIMPULAN}

Berdasarkan hasil pembahasan diatas dapat disimpulkan bahwa secara parsial Dana Pihak dan Pembiayaan keduanya sama-sama tidak berpengaruh secara signifikan terhadap Profitabilitas Bank Umum Syariah Di Indonesia Periode 2014-2018. Tetapi jika secara simultan Dana Pihak Ketiga dan Pembiayaan berpengaruh secara signifikan terhadap Profitabilitas Bank Umum Syariah Di Indonesia Periode 2014-2018.

Saran yang dapat diajukan dari hasil penelitian ini yakni bagi peneliti yang akan datang, penelitian ini selanjuntnya sebaiknya mengembangkan variabel-variabel yang diteliti, karena tidak menutup kemungkinan bahwa dengan penelitian yang mencakup lebih banyak variabel akan dapat menghasilkan hasil kesimpulan yang lebih baik.

\section{DAFTAR PUSTAKA}

Antonio, M. Syafi'i, 2011, Bank Syariah dari Teori ke Praktik, Jakarta: Gema Insani.

Dendawijaya, 2009. Manajemen Perbankan, Jakarta: Ghalia Indonesia.

Ismail, 2011. Perbankan Syariah, Jakarta: Kencana.

Karim, Adimarwan A, 2014, Bank Islam: Analisis Fiqih dan Keuangan, Jakarta: PT. Raja Grafindo Persada.

Kasmir, 2002, Bank dan Lembaga Keuangan Lainnya, Jakarta: Raja Grafindo Persada.

Kasmir, 2014, Manajemen Perbankan Edisi Revisi Jakarta: PT. Raja Grafindo Persada.

Kasmir, 2015, Manajemen Perbankan Edisi Revisi, Jakarta: Rajawali Pers. Mardani, 2014, Hukum Bisnis Islam, Jakarta: Kencana.

Riyanto, 2008, Dasar-Dasar Pembelanjaan Perusahaan, Yogyakarta;BPFE

Rivai, Veithzal dan Andria Pratama Veithzal, 2007, Islamic Financial Management, Jakarta: Gaya Media Pratama.

Simorangkir, 2004, Lembaga Keuangan Bank Dan Non Bank, (Jakarta: Fakultas Ekonomi Universitas Indonesia.

Siregar, Syofian, 2013, Metode Penelitian Kuantitatif, Jakarta: Prenadamedia Group. 
Sjahdeini, S. Remy, 2014, Perbankan Syariah Produk-Produk dan AspekAspek Hukumnya, Jakarta: Kencana.

Sujarweni, V. Wiratna, 2015, Metodologi Penelitian Bisnis dan Ekonomi, Yogyakarta: Pustaka Barupress.

Sutanto, Herry dan Khaerul Umam, 2013, Manajemen Pemasaran Bank Syariah, Bandung: Pustaka Setia.

Trijono, Rahmat, 2015, Metode Penelitian Kuantitatif, Jakarta: Penerbit Papas Sinar Sinanti.

Lubis, A. Khairani., 2017. Pengaruh Dana Pihak Ketiga, Pembiayaan, dan Modal Terhadap Laba Pada PT. Bank Syariah Mandiri, Skripsi Tidak Diterbitkan, Medan: UIN Sumatera.

Nizar, M, 2017, Pengaruh ekuivalen nisbah bagi hasil tabungan, deposito, dan frekuensi pencairan pembiayaan murabahah terhadap jumlah nasabah baru di BMT al-Yasini Wonorejo Pasuruan, MALIA: Jurnal Ekonomi Islam, 9 (1), 121-134.

Nizar, M, 2015, Implementasi Pembiayaan Murabahah Dalam Meningkatkan Profitabilitas. An-Nisbah: Jurnal Ekonomi Syariah, 2 (1), 227-256.

Nursucia, Giofani, 2017, Pengaruh Capital Adequacy Ratio (CAR), Non Performing Financing (NPF), Operational Efficiency Ratio (OER), Penyisihan Penghaspusan Aktiva Produktif (PPAP), Dan Net Operating Margin (NOM) Terhadap Profitabilitas Pada Bank Umum Syariah Periode 2010-2015, Skripsi Tidak Diterbitkan, Yogyakarta: Universitas Negeri Yogyakarta.

www.ojk.go.id diakses pada tanggal 11 Mei 2019 pukul 22.06. 
$20\}\{$ Pengaruh Dana Pihak Ketiga dan Pembiayaan Terhadap Profitabilitas 